\title{
GAMBARAN HISTOPATOLOGIK MUKOSA LAMBUNG TIKUS PUTIH (Rattus norvegicus) YANG DIINDUKSI KEBISINGAN DAN DIBERIKAN RANITIDIN
}

\author{
${ }^{1}$ Patricia Sembor \\ ${ }^{2}$ Poppy Lintong \\ ${ }^{2}$ Carla Kairupan
}

\author{
${ }^{1}$ Kandidat Skripsi Fakultas Kedokteran Universitas Sam Ratulangi Manado \\ ${ }^{2}$ Bagian Patologi Anatomi Fakultas Kedokteran Universitas Sam Ratulangi Manado \\ Email: patriciasembor@yahoo.com
}

\begin{abstract}
Abstrak: Bising memegang peranan yang sangat besar dalam menyebabkan stres. Stres bisa meningkatkan produksi asam lambung. Ranitidin merupakan obat untuk saluran cerna yang menghambat reseptor $\mathrm{H}_{2}$ secara selektif dan reversibel dalam meningkatkan produksi asam lambung. Tujuan penelitian untuk mengetahui pengaruh kebisingan terhadap gambaran histopatologik mukosa lambung dan efek pemberian ranitidin terhadap gambaran histopatologik mukosa lambung tikus wistar yang diinduksi kebisingan. Penelitian eksperimental ini dilakukan selama 5 bulan dengan menggunakan 25 ekor tikus wistar yang dibagi dalam 5 kelompok (masing-masing terdiri dari 5 ekor tikus). Kelompok 1 adalah kontrol negatif (KN). Kelompok 2 (P1) diinduksi bising selama 12 hari. Kelompok 3 (P2) diinduksi bising dan diberikan ranitidin secara bersamaan selama 12 hari. Kelompok 4 (P3) diinduksi bising selama 12 hari dan tidak mendapat perlakuan apapun pada 7 hari berikutnya. Kelompok 5 (P4) diinduksi bising selama 12 hari dan diberikan ranitidin pada 7 hari berikutnya. Bising diberikan dengan intesitas 90-95 dB selama 8 jam sehari. Ranitidin diberikan dengan dosis $0,9 \mathrm{mg} /$ hari. Hewan uji diterminasi dengan cara dekapitasi, kemudian organ lambung diambil dan diproses untuk dibuat preparat histologi dengan pengecatan HE. Analisis histopatologik dilakukan dengan menggunakan mikroskop cahaya di laboratorium Fakultas Kedokteran Universitas Sam Ratulangi Manado. Kelompok KN memberikan gambaran mikroskopik lambung normal. Kelompok P1, P3, dan P4 secara mikroskopik menunjukkan hasil yang hampir sama, yakni infiltrasi sel radang PMN, edema, dan vasodilatasi pembuluh darah pada mukosa lambung. Kelompok P2 menunjukkan infiltrasi sel radang PMN, edema dan vasodilatasi yang lebih sedikit dibandingkan dengan kelompok yang lain. Tikus yang diinduksi kebisingan menunjukkan tanda-tanda gastritis akut secara histopatologik. Pemberian ranitidin bersamaan dengan induksi kebisingan lebih baik dibandingkan dengan pemberian ranitidin setelah induksi kebisingan dalam terapi gastritis akibat stres oleh kebisingan.
\end{abstract}

Kata kunci: bising, gastritis, ranitidin.

\footnotetext{
Abstract: Noise has a big role in causing stress. Stress can increase gastric acid production. Ranitidine is a selective and reversible histamine H2-receptor antagonist that inhibits gastric acid production. The objectives of this research were to study the histopathology of noiseexposed gastric mucous and the effects of ranitidine on histopathology noise-exposed gastric mucous. This study was an experimental research. The research was conducted in 5 months. 25 healthy rats were divided into 5 groups, 5 rats for each group. Group 1 (KN) was a controlled group. Group 2 (P1) was exposed by noise in 12 days. Group 3 (P2) was exposed by noise and ranitidine in 12 days. Group 4 (P3) was exposed by noise in 12 days and not given any treatment for the next 7 days. Group 5 (P4) was exposed by noise in 12 days and
} 
ranitidine for the next 7 days. Noise was given with the intensity of 90-95 decibel. Ranitidine was given with doses of $0.9 \mathrm{mg} /$ day. The data collection was conducted after the latest treatment for each group by taking out the gastric of the sacrificed rats. Gastric microscopic slides were prepared using paraffin method and stained with hematoxylin eosin staining. Gastric specimen was studied using light microscopy. Group 1 showed a normal histology of gastric. Group 2, 4, and 5 showed the infiltration of polymorph nuclear leukocytes (PMN) cell, edema, and vasodilatation on the gastric mucous. Group 3 showed less infiltrations of polymorph nuclear leukocytes (PMN) cell, edema, and vasodilatation on the gastric mucous compared to the other 3 groups. Histopathology study showed that signs of acute gastritis present in the noise-exposed gastric mucous. Ranitidine treatment together with the noise exposed still showed the signs of acute gastritis although less PMN cell present.

Keywords: gastritis, noise, ranitidine.

Bising didefinisikan sebagai suara yang tidak dikehendaki atau yang mengganggu kesehatan dan kenyamanan. ${ }^{1}$ Paparan kebisingan dengan intensitas yang tinggi, melebihi Nilai Ambang Batas (NAB) yang ditetapkan pemerintah melalui KEPMENAKER No. 51/MEN/1999 (85 dB untuk paparan 8 jam kerja sehari), akan membahayakan kesehatan. ${ }^{2}$ Bising memegang peranan yang besar dalam menyebabkan stres. Hasil penelitian menunjukkan bahwa prevalensi stres di tempat kerja dengan tingkat kebisingan yang tinggi mencapai 55\%, sedangkan di tempat kerja dengan tingkat kebisingan yang rendah hanya $24.5 \% .^{3} \quad$ Penelitian yang lain juga membuktikan bahwa bising dengan intensitas 90-95 dB selama 8 jam sehari dalam 12 hari dapat menyebabkan kondisi stres Exhaustion stage dan kerusakan mukosa lambung tikus putih. ${ }^{4}$ Stres dapat menimbulkan gejala fisik dan menyebabkan gangguan psikologis, dimana jika berlangsung dalam jangka waktu lama dapat menimbulkan penyakit seperti gastritis. ${ }^{1,2}$

Gastritis adalah keadaan dimana mukosa dan submukosa lambung mengalami inflamasi. ${ }^{5,6}$ Salah satu faktor penyebab gastritis adalah stres, karena stres bisa meningkatkan produksi $\mathrm{HCl}^{7,8}$ Menurut WHO, kejadian gastritis paling tinggi ditemukan di Amerika dengan presentasi mencapai $47 \%$, diikuti oleh India (43\%) dan Indonesia (40,85\%). Berdasarkan hasil penelitian dan pengamatan yang dilakukan oleh Departemen Kesehatan Republik Indonesia, angka kejadian gastritis di beberapa kota di Indonesia mencapai $91,6 \%{ }^{7}$ Tahun 2010, gastritis menempati urutan pertama dalam 10 besar penyakit rawat inap di rumah sakit dan menempati urutan kelima dalam 10 besar penyakit rawat jalan. ${ }^{9}$

Ranitidin merupakan obat untuk saluran cerna yang menghambat reseptor $\mathrm{H}_{2}$ secara selektif dan reversibel. Perangsangan reseptor $\mathrm{H}_{2}$ akan merangsang sekresi asam lambung. Pada pemberian ranitidin, sekresi asam lambung akibat obat muskarinik, stimulasi vagus, atau gastrin akan dihambat sampai 5 jam. ${ }^{10-12}$ Penelitian ini dilakukan untuk mengetahui gambaran histopatologik mukosa lambung tikus wistar yang diinduksi kebisingan dan diberikan ranitidin.

\section{METODE PENELITIAN}

Penelitian ini merupakan penelitian eksperimental yang dilakukan pada Bulan Oktober 2012 sampai Maret 2013. Penelitian dilakukan di Laboratorium Riset Terpadu di Bagian Patologi Anatomi Fakultas Kedokteran Universitas Sam Ratulangi Manado. Variabel bebas dalam penelitian ini adalah ranitidin dan kebisingan, sedangkan variabel terikat adalah gambaran histopatologik mukosa lambung. Subyek penelitian adalah tikus wistar berjumlah 25 ekor yang dibagi dalam 5 kelompok, yaitu kelompok kontrol negatif (KN), kelompok perlakuan 1 (P1), kelompok perlakuan 2 (P2), kelompok perlakuan 3 (P3) dan kelompok perlakuan 4 (P4). Kelompok KN terdiri dari lima ekor tikus wistar yang diberi diet standar selama 
12 hari. Kelompok P1 terdiri dari lima ekor tikus wistar yang diberi diet standar dan dipapar dengan kebisingan selama 12 hari.Kelompok P2 terdiri dari lima ekor tikus wistar yang diberi diet standar serta secara bersamaan dipapar dengan kebisingan selama 12 hari dan diberi terapi Ranitidin. Kelompok P3 terdiri dari lima ekor tikus wistar yang diberi diet standar dan dipapar dengan kebisingan selama 12 hari dan pada hari ke 13-19 (7 hari) tidak diberikan terapi ranitidin, hanya diberikan diet standar. Kelompok P4 terdiri dari lima ekor tikus wistar yang diberi diet standar dan dipapar dengan kebisingan selama 12 hari dan pada hari ke 13-19 (7 hari) diberi terapi Ranitidin.

Ranitidin diberikan secara oral sebanyak $0.9 \mathrm{mg}$ (setara dengan $300 \mathrm{mg}$ pada orang dewasa). ${ }^{11,13}$ Ranitidin diberikan dengan menggunakan semprit 1 cc yang telah dimodifikasi ujungnya dengan menggunakan Nasogastric Tube (NGT) pediatrik no.3. Nasogastric Tube dimasukkan melalui mulut sampai mencapai lambung. Kebisingan diberikan dengan menggunakan sirine dengan intensitas kebisingan 9095dB selama 8 jam sehari. ${ }^{4}$ Intensitas kebisingan diukur dengan menggunakan Sound Level Meter.

\section{HASIL DAN PEMBAHASAN}

Bising intensitas tinggi dapat menyebabkan gangguan kesehatan. ${ }^{1,2}$ Gangguan kesehatan yang ditimbulkan antara lain berupa stres. Stres dapat menyebabkan gangguan mukosa lambung atau gastritis. ${ }^{3-6}$ Gastritis seringkali tidak menunjukkan kelainan saat endoskopi, namun pada pemeriksaan histopatologik terlihat edema mukosa dan infiltrat sel radang neutrofil. ${ }^{14,15}$ Hasil yang didapatkan pada penelitian ini mendukung teori hubungan bising dan gangguan mukosa lambung tersebut. Secara mikroskopik, lambung tikus kelompok perlakuan menunjukkan gambaran yang berbeda dengan kelompok kontrol negatif yang memiliki gambaran lambung normal.

Tikus kelompok P1 yang diinduksi dengan kebisingan 90-95 dB selama 8 jam per hari dalam jangka waktu 12 hari menunjukkan lambung dengan gambaran histopatologik gastritis akut, yaitu adanya infiltrasi sel-sel radang PMN, vasodilatasi dan edema (gambar 1B). Hasil penelitian ini sesuai dengan penelitian yang dilaporkan sebelumnya bahwa paparan bising dengan intensitas 90-95 dB selama 8 jam sehari dalam waktu 12 hari menyebabkan tanda-tanda gastritis seperti hiperemi, edema, dan sebaran sel-sel radang. ${ }^{4}$

Stres yang terjadi karena paparan bising dapat meningkatkan produksi asam lambung. ${ }^{4,15}$ Peningkatan asam lambung secara fisiologik terjadi melalui jalur neurogen dan neurohormonal. Pada jalur neurogen terjadi pelepasan asetilkolin dan Gastrin releasing peptide (GRP) oleh rangsangan saraf vagus. Asetilkolin merangsang sel-sel parietal secara langsung. Gastrin releasing peptide merangsang pelepasan gastrin oleh sel G. Gastrin merangsang sel-sel parietal secara langsung dan juga merangsang pelepasan histamin oleh ECL yang pada akhirnya meningkatkan produksi asam lambung. Selain itu, pada jalur neurohormonal, hormon adrenal juga berperan dalam merangsang sekresi asam lambung. ${ }^{16,17}$

Dibandingkan dengan lambung tikus wistar kelompok P1, lambung tikus wistar yang mendapatkan ranitidin secara oral sebanyak 0,9 mg (kelompok P2) secara bersamaan dengan induksi kebisingan menunjukkan tanda-tanda gastritis yang lebih ringan secara mikroskopik (gambar 1C). Pemberian ranitidin akan menurunkan sekresi asam lambung dengan cara menghambat stimulasi dari histamin dan gastrin terhadap sel-sel parietal. $^{11}$ Ranitidin menurunkan sekresi asam yang distimulasi oleh histamin maupun gastrin melalui dua mekanisme. Pertama, histamin yang dilepaskan dari sel ECL (Enterochromaffinlike) oleh gastrin atau pun stimulasi vagus dihambat untuk mengikat $\mathrm{H}_{2}$ reseptor pada sel-sel parietal. Kedua, menghambat stimulasi langsung ke sel-sel parietal oleh gastrin atau asetilkolin dalam mengurangi sekresi asam. $^{18}$ 


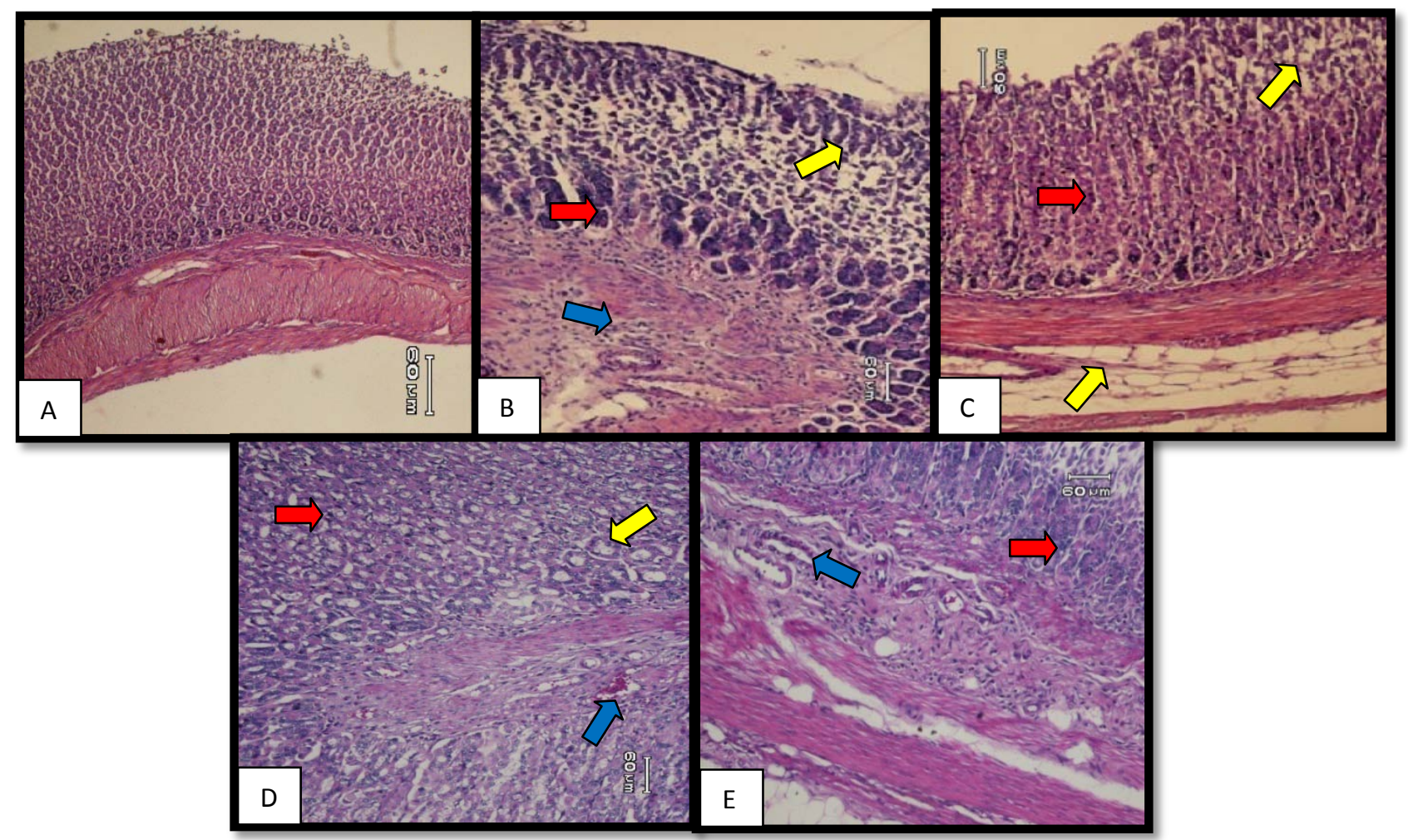

Gambar 1. Gambaran mikroskopik lambung. A: kelompok $1(\mathrm{KN})$ menunjukkan gambaran normal. B: kelompok 2 (P1). C: kelompok 3 (P2). D: kelompok 4 (P3). E: kelompok 5 (P4). B, C, E menunjukkan adanya infiltrasi sel radang PMN, edema dan vasodilatasi. D menunjukkan sel-sel radang PMN dan edema lebih sedikit. Panah merah: sel-sel PMN, panah kuning: edema, panah biru: vasodilatasi.

Tikus yang diinduksi bising dengan intensitas 90-95 dB selama 8 jam sehari dalam jangka waktu 12 hari kemudian pada hari ke-13 sampai hari ke-19 tidak diberikan perlakuan apapun (kelompok P3) dan tikus yang diinduksi bising dengan intensitas 90-95 dB selama 8 jam sehari dalam jangka waktu 12 hari kemudian pada hari ke-13 sampai hari ke-19 diberikan terapi ranitidin sebanyak $0,9 \mathrm{mg}$ per hari (kelompok 4) menunjukkan hasil yang hampir sama, yakni secara mikroskopik pada lambung masih terlihat adanya infiltrasi sel-sel radang PMN, edema dan vasodilatasi. Hal ini menunjukkan bahwa sesudah terjadi gastritis akut, penggunaan ranitidin dalam jangka waktu 7 hari belum bisa memperbaiki kerusakan lambung meskipun induksi dengan kebisingan sudah dihentikan. Pemberian terapi kombinasi ranitidin dan sukralfat pada penelitian sebelumnya terbukti menghilangkan keluhan pasien gastritis akut maupun kronis dengan persentase 100\%. Demikian juga dengan terapi kombinasi ranitidin dan antasida dapat menghilangkan keluhan gastritis sampai $80 \% .^{19}$

Secara mikroskopik, lambung tikus kelompok P2 (pemberian ranitidin bersamaan dengan pemaparan bising) dan kelompok P4 (pemberian ranitidin setelah pemaparan bising dihentikan) memiliki hasil yang berbeda. Kelompok P2 menunjukkan perbaikan dengan berkurangnya tanda-tanda gastiritis akut, sedangkan kelompok P4 menunjukkan tanda-tanda gastritis akut yang lebih berat. Hasil ini menunjukkan bahwa pemberian terapi ranitidin bersamaan dengan pemaparan bising lebih baik dibandingkan dengan pemberian ranitidin setelah pemaparan bising dihentikan dalam penanganan gastritis akibat kebisingan. Jadi, ranitidin dapat dijadikan first-line agent untuk menurunkan sekresi asam lambung karena memiliki tingkat toleransi yang baik dan 
sangat sedikit reaksi anafilaktik yang dilaporkan pada penggunaannya. ${ }^{20}$ Walaupun demikian, penggunaan ranitidin harus tetap diperhatikan karena kasus reaksi anafilaktik pada kehamilan, pasien pankreatitis dan pasien Benign Prostatic Hyperplasia (BPH) pernah dilaporkan. ${ }^{21}$

\section{SIMPULAN DAN SARAN}

Gambaran histopatologik jaringan lambung tikus wistar yang diinduksi kebisingan dengan intensitas $90-95 \mathrm{~dB}$ per hari selama 12 hari menunjukkan tandatanda gastritis akut. Selain itu juga, dapat disimpulkan bahwa pemberian ranitidin dengan dosis 0,9 mg/hari (150 mg x 2 tablet per hari, pada manusia) bersamaan dengan induksi kebisingan menunjukkan tanda-tanda gastritis yang minimal, sedangkan pemberian ranitidin dengan dosis sama setelah induksi kebisingan dihentikan masih menunjukkan tanda-tanda gastritis yang jelas. Penelitian selanjutnya dapat dikembangkan dalam skala yang lebih besar dan waktu penelitian yang lebih lama disertai analisa statistik untuk menilai kerusakan mukosa lambung secara kuantitatif. Pada penelitian lebih lanjut, penggunaan ranitidin setelah induksi kebisingan dengan intensitas 90-95 dB dapat juga diperpanjang dan dapat digunakan terapi kombinasi pada tikus yang telah mengalami kerusakan lambung oleh karena kebisingan.

\section{DAFTAR PUSTAKA}

1. Buchari. Kebisingan industri dan hearing conservation program [Skripsi]. Medan: Universitas Sumatera Utara; 2007.

2. Nawawinetu DE, Adriyani R. Stress akibat kerja pada tenaga kerja yang terpapar bising. The Indonesian Journal of Public Health. 2007;4(2):59-63.

3. Mursali A, Basuki E, Dharmono S. Relationship between noise and job stress at a private thread spinning company. Univ Med. 2009;28:8-16.

4. Hartono, Muthmainah. Pengaruh perbedaan intensitas kebisingan terhadap gambaran struktur histologi lambung pada tikus putih (Rattus norvegicus). Jurnal Kedokteran Yarsi. 2007;15(2):133-8.

5. Sudoyo A, Setiyohadi B, Alwi I, Simadibrata KM, Setiati S. Ilmu penyakit dalam I (Edisi V). Jakarta: Interna Publising, 2010; p.509-12.

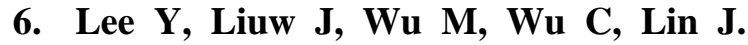
Gastritis. NIDDK. 2008;1(2):111-20.

7. Akmal M, Indahaan Z, Widhawati, Sari S. Ensiklopedi kesehatan. Jogjakarta: Arruzz Media, 2010; p.215-16.

8. Kusumadewi M. Faktor-faktor yang berhubungan dengan kekambuhan gastritis di wilayah kerja puskesmas kedungmundu semarang [Thesis]. Semarang: Universitas Muhammadiyah Semarang; 2012.

9. Departemen Kesehatan Republik Indonesia.Profil data kesehatan Indonesia tahun 2010 [homepage on the Internet]. 2010 [cited 2012 Oct 19]. Available from: www.depkes.go.id/downloads/Profil_Kese hatan_Indonesia_2010.pdf.

10. Dinas Kesehatan Kota Tasikmalaya. Ranitidin [homepage on the Internet]. Nodate [cited 2012 Oct 19]. Available from: www.dinkes.tasikmalaya.go.id/ index.php/informasi-obat/354-ranitidin.pdf.

11. Gunawan SG. Farmakologi dan terapi. (Edisi Kelima). Jakarta: Balai Penerbit FKUI, 2008; p.282-3.

12. Akbar HF, Sugiyartono, Setiawan D. Pengaruh penambahan manitol terhadap pelepasan ranitidin hcl dari tablet floating dengan hpmc k100m sebagai matriks. Pharma Scientia. 2012;1(1):30-45.

13. Daily med. Ranitidine tablet, film coated [homepage on the Internet]. Nodate [cited 2012 Oct 19. Available from: http://dailymed.nlm.nih.gov/dailymed/drug Info.cfm?id=68973.

14. Rani A, Simadibrata M, Syam AF. Buku Ajar Gastroenterologi. Jakarta: Interna Publishing, 2011; p.307.

15. Kumar V, Cotran RS, Robbins SL. Buku ajar patologi (Edisi Ketujuh). Jakarta: Penerbit Buku Kedokteran ECG, 2007; p.624-625.

16. Price SA, Wilson LM. Patofisologi Konsep Klinis Proses-Proses Penyakit (Edisi Keenam). Jakarta: Penerbit Buku Kedokteran EGC; 2005. h.417-423.

17. McCance KL, Huether SE, Brashers VL, Rote NS. Pathophysiology the biologic basis for disease in adults and children. 
Sixth Edition. Missouri: Mosby Elsevier; 2010; p.1423-8.

18. Katzung BG. Basic and clinical pharmacology (Tenth Edition). United States: McGraw Hill, 2007; p.1010-2.

19. Cook D, Guvatt G, Marshall J, et al. A comparison of sulcrafate and ranitidine for the prevention of upper gastrointestinal bleeding in patients requiring mechanical ventilation. N Eng J Med. 1998;338:791797.
20. Grant SM, Langtry HD, Brogden RN. Ranitidine. An updated review of its pharmacodynamic and pharmacokinetic properties and therapeutic use in peptic ulcer disease and other allied disease. Europe Pubmed Central. 1989;37(6):801870.

21. Oliva A, Partemi S, Arena V, DeGiorgio F, Colecchi C, Fucci N, et al. Fatal injection of ranitidine: a case report. Biomed Central. 2008;232(2):1-5. 